\title{
C-C motif chemokine ligand 2 induces proliferation and prevents lipopolysaccharide-induced inflammatory responses in bovine mammary epithelial cells
}

\author{
Changwon Yang, ${ }^{* 1}$ Whasun Lim,$\dagger^{1}$ Hyocheol Bae, ${ }^{*}$ Fuller W. Bazer, $\ddagger$ and Gwonhwa Song ${ }^{* 2}$ \\ *Institute of Animal Molecular Biotechnology, Department of Biotechnology, College of Life Sciences and Biotechnology, Korea University, Seoul, \\ 02841, Republic of Korea \\ †Department of Biomedical Sciences, Catholic Kwandong University, Gangneung, 25601, Republic of Korea \\ ¥Center for Animal Biotechnology and Genomics, Department of Animal Science, Texas A\&M University, College Station 77843-2471
}

\section{ABSTRACT}

C-C motif chemokine ligand 2 (CCL2) is a small chemokine which belongs to the CC-type chemokine family, and has chemoattractant activity for recruitment of monocytes to sites of inflammation. Overexpressed CCL2 binding to its receptor C-C chemokine receptor 2 increases the risk of breast cancer in humans, but its effects on proliferation of bovine mammary epithelial cells is not known. Maintaining a high level of proliferative activity in bovine mammary epithelial cells during lactation is important for improving milk yield and can benefit the dairy industry economically. In the present study, we demonstrated that CCL2 induces proliferation of MAC-T cells, a bovine mammary epithelial cell line, and stimulates progression of the cell cycle through stimulation of expression of cyclin D1. Moreover, CCL2 activates phosphoinositide 3-kinase (PI3K)/AKT [AKT, P70-S6 kinase 1 (P70S6K), ribosomal protein $\mathrm{S} 6(\mathrm{~S} 6)]$ and mitogen activated protein kinase (MAPK) [extracellular signal-regulated kinase-1/2 (ERK1/2), c-Jun N-terminal kinase (JNK), and P38] pathways, which are involved in proliferation of MAC-T cells, as evidenced by co-treatment of MAC$\mathrm{T}$ cells with pharmacological inhibitors of cell signaling transcription factors including Wortmannin, U0126, and SP600125. The CCL2 in MAC-T cells attenuates endoplasmic reticulum stress induced by tunicamycin, suggesting that CCL2 regulates intracellular synthesis of proteins and lipids and prevents activation of apoptotic pathways initiated in response to endoplasmic reticulum stress. Furthermore, CCL2 is involved in alleviating lipopolysaccharide (LPS)-induced inflammatory

\footnotetext{
Received October 10, 2017.

Accepted December 29, 2017.

${ }^{1}$ These authors contributed equally to this work.

${ }^{2}$ Corresponding author: ghsong@korea.ac.kr
}

responses in MAC-T cells by reducing LPS-induced expression of $I L 8, I L 6$, and nuclear factor kappa B subunit 1 (NFKB1). Collectively, CCL2 is a novel target for improving the quantity and quality of milk from cows through stimulation of proliferation on mammary epithelial cells and attenuation of LPS-induced inflammatory responses.

Key words: CCL2, bovine mammary epithelial cells, proliferation, ER stress, inflammation

\section{INTRODUCTION}

Bovine milk is the primary source of nutrition for calves throughout lactation (Nissen et al., 2013), and it is also a source of many dairy products and has tremendous economic value (Haug et al., 2007). Therefore, milk production, in both quantity and quality, is important in the dairy industry. The mammary gland is composed of epithelial cells in alveoli, although several types of accessory cells exist, including fibroblasts, adipocytes, and endothelial cells. The secretory activity of mammary epithelial cells is essential for milk production (Dessauge et al., 2011). The biological activity of reproductive hormones, lactogenic hormones, growth factors, and cytokines, affecting the loss and replacement of secretory cells of the mammary gland of cows during lactation, play important roles in the normal growth, development, and differentiation of mammary epithelial cells (Leibowitz and Cohick, 2009; Wang et al., 2016). The kinase proteins involved in the phosphoinositide 3-kinase (PI3K)/AKT and mitogenactivated protein kinase (MAPK) pathways are the main targets in initiating mechanisms whereby various growth factors stimulate proliferation of bovine mammary epithelial cells (Hou et al., 2016).

Moreover, along with the need for the synthesis of milk fat and milk protein during lactation, bovine mammary epithelial cells undergo extreme metabolic stress (Bauman et al., 2011). As seen in development of 
mouse mammary glands, maintaining endoplasmic reticulum (ER) homeostasis and modulating the unfolded protein response (UPR) pathway is important for lipid homeostasis, as well as synthesis of intracellular proteins (Bobrovnikova-Marjon et al., 2008). Furthermore, severe ER stress leads to apoptosis, and chemicals such as resveratrol alleviate ER stress in bovine mammary epithelial cells and have value as therapeutic agents for ruminants (Jin et al., 2016).

A variety of chemokines are found in human mammary glands and milk and are required for development and differentiation of mammary glands due to their chemotactic functions (Gouon-Evans et al., 2002; Suzuki et al., 2015). C-C motif chemokine ligand 2 (CCL2), also known as monocyte chemoattractant protein-1 (MCP1), plays a role in migration and infiltration of monocytes and macrophages, and overexpression of CCL2 appears to increase the risk of breast cancer in a transgenic mouse model (Kitamura et al., 2015; Sun et al., 2017). However, it is unclear whether the activity of CCL2 is involved in the proliferation and apoptosis of bovine mammary epithelial cells and related cell signaling pathways. The CCL2 generally induces inflammatory responses through monocyte infiltration, but it also acts as an anti-inflammatory agent at low concentrations (Flaishon et al., 2008). The expression of CCL2 in mammary epithelial cells of goats increases in response to LPS, but it is unknown whether CCL2 can control mastitis in cows (Bulgari et al., 2017).

We investigated whether proliferation and abundance of cell cycle proteins in a bovine mammary epithelial cell line (MAC-T) are regulated by CCL2. In addition, we confirmed activation of PI3K/AKT and MAPK pathways, which are signal transduction pathways involved in cell proliferation by CCL2 in MAC-T cells. The effect of CCL2 on proliferation of MAC-T cells was also investigated in the presence of specific inhibitors of cell signaling protein kinases. Finally, we determined if CCL2 modulated ER stress and alleviated inflammatory responses of MAC-T cells to LPS.

\section{MATERIALS AND METHODS}

\section{Cell Culture}

Bovine mammary epithelial cells (MAC-T cells) were a gift from Hong Gu Lee (Konkuk University, Seoul, Republic of Korea). Briefly, the MAC-T cell line was developed by immortalizing primary bovine mammary alveolar cells by stable transfection with a replicationdefective retrovirus (SV40) large T-antigen as described previously (Huynh et al., 1991). The MAC-T cells displayed a cobblestone shape when grown on a plastic substratum. They formed a single monolayer at confluence. All analyses in the present study were performed using MAC-T cells between passages 25 to 30. Briefly, monolayer MAC-T cells were grown in Dulbecco's Modified Eagle's Medium (DMEM, HyClone, Logan, UT) containing 10\% fetal bovine serum to $80 \%$ confluence in 100-mm tissue culture dishes. For assays, in vitro cultured MAC-T cells were serum starved for $24 \mathrm{~h}$ before treatment and then incubated in the presence of various concentrations of CCL2. Experiments were performed in triplicate.

\section{Reagents}

Recombinant CCL2 (catalog number: 279-MC/CF) was purchased from R\&D Systems (Minneapolis, MN). Tunicamycin (catalog number: T7765) and LPS (catalog number: L3491) were purchased from Sigma-Aldrich Inc. (St. Louis, MO). The antibodies against phosphorylated AKT (Ser ${ }^{473}$, catalog number: 4060), P70S6K ( $\mathrm{Thr}^{421} / \mathrm{Ser}^{424}$, catalog number: 9204), S6 ( $\mathrm{Ser}^{235 / 236}$, catalog number: 2211$)$, ERK1/2 $\left(\mathrm{Thr}^{202} / \mathrm{Tyr}^{204}\right.$, catalog number: 9101), JNK ( $\mathrm{Thr}^{183} / \mathrm{Tyr}^{185}$, catalog number: 4668), P38 ( $\mathrm{Thr}^{180} / \mathrm{Tyr}^{182}$, catalog number: 4511), cyclin D1 ( $\mathrm{Thr}^{286}$, catalog number: 3300), and eIF2 $\alpha\left(\mathrm{Ser}^{51}\right.$, catalog number: 3398) and total AKT (catalog number: 9272), P70S6K (catalog number: 9202), S6 (catalog number: 2217), ERK1/2 (catalog number: 4695), JNK (catalog number: 9252), P38 (catalog number: 9212), cyclin D1 (catalog number: 2922), eIF2 $\alpha$ (catalog number: 5324), and IRE1 $\alpha$ (catalog number: 3294) were purchased from Cell Signaling Technology (Beverly, MA). The antibodies against PCNA (catalog number: sc-56), ATF6 $\alpha$ (catalog number: sc-166659), phosphorylated PERK (Thr ${ }^{981}$, catalog number: sc-32577), total PERK (catalog number: sc-13073), GRP78 (catalog number: sc-13968), and GADD153 (catalog number: sc7351) were purchased from Santa Cruz Biotechnology Inc. (Santa Cruz, CA). For Western blot analyses, all antibodies were diluted 1:1,000 and incubated at $4^{\circ} \mathrm{C}$ for $16 \mathrm{~h}$ to allow binding to the target proteins. Inhibitors for ERK1/2 (U0126, catalog number: EI282) and JNK (SP600125, catalog number: EI305) were obtained from Enzo Life Sciences Inc. (Farmingdale, NY), and PI3K/AKT inhibitor (Wortmannin, catalog number: 9951) was from Cell Signaling Technology Inc.

\section{Proliferation Assay}

Proliferation assays were conducted using a Cell Proliferation ELISA, BrdU kit (Cat No. 11647229001, Roche, Basel, Switzerland) according to the manufac- 
turer's recommendations (https://www.sigmaaldrich .com/content/dam/sigma-aldrich/docs/Roche/ Bulletin/1/11647229001bul.pdf). Briefly, the MAC$\mathrm{T}$ cells were seeded in a 96-well plate and grown to $80 \%$ confluence. Cells were then incubated for $24 \mathrm{~h}$ in serum-free DMEM/high-glucose culture medium. Cells were then treated with CCL2 alone $(0,1,5,10,25,50$, 100 , and $150 \mathrm{ng} / \mathrm{mL}$ ) or in combination with various treatments in a final volume of $100 \mu \mathrm{L} /$ well. After $48 \mathrm{~h}$ of incubation, $10 \mu M$ 5-bromo-2'-deoxyuridine (BrdU) was added to the cell culture medium and the cells were incubated for an additional $2 \mathrm{~h}$ at $37^{\circ} \mathrm{C}$. After labeling cells with BrdU, the fixed cells were incubated with anti-BrdU-peroxidase working solution for $90 \mathrm{~min}$. The anti-BrdU- peroxidase binds to BrdU incorporated into newly synthesized cellular DNA, and these immune complexes were detected following their reaction to the $3,3^{\prime}, 5,5^{\prime}$-tetramethylbenzidine substrate. The absorbance values of the reaction product were quantified by measuring the absorbance at 370 and $492 \mathrm{~nm}$ using an ELISA reader. Experiments were performed in triplicate.

\section{Immunofluorescence Analysis}

The effects of CCL2 on the expression of proliferating cell nuclear antigen (PCNA) and cyclin D1 were determined using immunofluorescence microscopy. The MAC-T cells $\left(3 \times 10^{4}\right.$ cells per $\left.300 \mu \mathrm{L}\right)$ were seeded on confocal dishes (catalog number: 100350, SPL Life Science, Pocheon-si, Republic of Korea) and grown to $80 \%$ confluence. Cells were then incubated for $24 \mathrm{~h}$ in serum-free DMEM/high-glucose culture medium. For detection of PCNA and cyclin D1 protein, the serumstarved cells were treated with CCL2 $(50 \mathrm{ng} / \mathrm{mL})$ for $24 \mathrm{~h}$. The cells were fixed using methanol and probed with mouse anti-human monoclonal antibody to PCNA and rabbit anti-human polyclonal cyclin D1 at a final dilution of $1: 100$ at $4^{\circ} \mathrm{C}$ for $16 \mathrm{~h}$. Negative controls for background staining included substitution of the primary antibody with purified nonimmune mouse $\operatorname{IgG}$ or rabbit IgG. Cells were then incubated with goat anti-mouse IgG Alexa 488 (catalog number: A11017, Invitrogen, Carlsbad, CA) or goat anti-rabbit IgG Alexa 488 (catalog number: A-11008, Invitrogen) at a 1:200 dilution for $1 \mathrm{~h}$ at room temperature. The MAC$\mathrm{T}$ cells were then washed using $0.1 \% \mathrm{BSA}$ in PBS and overlaid with 4',6-diamidino-2-phenylindole (DAPI). For each primary antibody, images were captured using a LSM710 (Carl Zeiss, Thornwood, NY) confocal microscope fitted with a digital microscope Axio-Cam camera and Zen2009 software (Carl Zeiss, Thornwood, NY). Experiments were performed in triplicate. Relative fluorescence intensities were quantified using
green/DAPI ratios and MetaMorph software (Molecular Devices, Sunnyvale, CA).

\section{Cell Cycle Analysis}

Cells were seeded in a 6-well plate and grown to $80 \%$ confluence. Cells were then incubated for $24 \mathrm{~h}$ in serum-free DMEM/high-glucose culture medium. Cells were then treated with CCL2 in a dose-dependent manner $(0,5,10,25$, and $50 \mathrm{ng} / \mathrm{mL})$ for $48 \mathrm{~h}$. After treatment, the cells were centrifuged $(700 \times g$ for 5 min at room temperature), washed twice with cold $0.1 \%$ BSA in PBS, and fixed in $70 \%$ ethanol at $4^{\circ} \mathrm{C}$ for $24 \mathrm{~h}$. The MAC-T cells were then centrifuged $(700 \times g$ for $5 \mathrm{~min}$ at room temperature) and the supernatant discarded. Pellets were washed twice with $0.1 \%$ BSA in PBS and stained with propidium iodide (BD Biosciences, Franklin Lakes, NJ) in the presence of $100 \mu \mathrm{g} / \mathrm{mL}$ of RNase A (Sigma-Aldrich) for $30 \mathrm{~min}$ in the dark. Fluorescence intensity was analyzed using a flow cytometer (BD Biosciences).

\section{Western Blot Analyses}

Concentrations of protein in whole-cell extracts were determined using the Bradford protein assay (Bio-Rad, Hercules, CA) with BSA as the standard. Proteins were denatured, separated using SDS-PAGE, and transferred to nitrocellulose. Blots were developed using enhanced chemiluminescence detection (SuperSignal West Pico, Pierce, Rockford, IL) and quantified by measuring the intensity of light emitted from the bands representing the correct size of proteins under UV light using a ChemiDoc EQ system and Quantity One software (BioRad). Immunoreactive proteins were detected using goat anti-rabbit or mouse polyclonal antibodies against phosphorylated proteins and total proteins at a 1:1,000 dilution. Antibodies and proteins were incubated at $4^{\circ} \mathrm{C}$ for $16 \mathrm{~h}$ following separation of proteins using $10 \%$ SDS-PAGE gels. Goat anti-rabbit IgG polyclonal antibody (catalog number: 474-1506, Seracare, Milford, MA,) and goat anti-mouse IgG polyclonal antibody (catalog number: 474-1806, Seracare) were then diluted 1:2,500 and incubated at room temperature for $1 \mathrm{~h}$. Expression of total protein was measured to normalize the result of detecting the expression of phosphorylated proteins. Multiple exposures of each Western blot were performed to ensure linearity of chemiluminescent signals. Experiments were performed in triplicate.

\section{RNA Isolation and cDNA Synthesis}

Total cellular RNA was isolated from MAC-T cells using Trizol reagent (Invitrogen) and purified using an 
Table 1. Primer sets used in quantitative PCR

\begin{tabular}{llll}
\hline Gene symbol & GenBank accession no. & Sense primer $\left(5^{\prime} \rightarrow 3^{\prime}\right)$ & Antisense primer $\left(5^{\prime} \rightarrow 3^{\prime}\right)$ \\
\hline$I L 8$ & NM_001256799 & CAGAACTTCGATGCCAATGC & TTTAGGCAGACCTCGTTTCC \\
$I L 6$ & NM_001025366 & CTACCTCCAGAACGAGTATG & CAGCAGGTCAGTGTTTGTGG \\
NFKB1 & NM_001159920 & CTTTCCTTCCAGACAGCACC & TCCCCTCCAGTTACACATCC \\
GAPDH & NM_001127891 & CACAGTCAAGGCAGAGAACG & TACTCAGCACCAGCATCACC \\
\hline
\end{tabular}

RNeasy Mini Kit (Qiagen, Hilden, Germany) according to the manufacturer's recommendations (https://www .qiagen.com/se/resources/resourcedetail?id=14e7cf6e

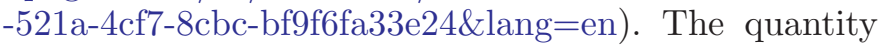
and quality of total RNA was determined by spectrometry and denaturing agarose gel electrophoresis, respectively. Complementary DNA was synthesized from cellular RNA using AccuPower RT PreMix (Bioneer, Daejeon, Republic of Korea), random hexamers (Invitrogen), and oligo (dT) primers.

\section{Quantitative PCR Analysis}

Specific primers for bovine IL8, IL6, and NFKB1 were designed from sequences in the GenBank database using Primer 3 (ver 4.0.0, Free Software Foundation Inc., Boston, MA). Primer sets are listed in Table 1. All primers were synthesized by Bioneer. The PCR conditions were $95^{\circ} \mathrm{C}$ for $3 \mathrm{~min}$ followed by 40 cycles at $95^{\circ} \mathrm{C}$ for $20 \mathrm{~s}, 64^{\circ} \mathrm{C}$ for $40 \mathrm{~s}$, and $72^{\circ} \mathrm{C}$ for 1 min using a melting curve program (increasing the temperature from 55 to $95^{\circ} \mathrm{C}$ at $0.5^{\circ} \mathrm{C}$ per $10 \mathrm{~s}$ ) and continuous fluorescence measurements. Sequence-specific products were identified by generating a melting curve in which the cycle threshold (CT) value represented the number of cycles required for the fluorescence signal to exceed background level. Relative gene expression was quantified using the $2^{-\triangle \triangle \mathrm{CT}}$ method. The $G A P D H$ gene was used as the endogenous control to standardize the amount of RNA in each reaction. Experiments were performed in triplicate.

\section{Semiquantitative Real-Time PCR Analysis}

Specific primers for bovine CCR2, CCL2, and GAP$D H$ (housekeeping gene) were designed from sequences in the GenBank database using Primer 3 (ver. 4.0.0).
Primer sets are listed in Table 2. All primers were synthesized by Bioneer. The expression of target mRNA in MAC-T cells was investigated using semiquantitative real-time PCR. After PCR, equal amounts of reaction product were analyzed using a $1 \%$ agarose gel, and PCR products were visualized using ethidium bromide staining. The amount of DNA present was quantified by measuring the intensity of light emitted from correctly sized bands under UV light using a Gel Doc XR ${ }^{+}$ system with Image Lab software (Bio-Rad).

\section{Statistical Analyses}

All quantitative data were subjected to least squares ANOVA using the general linear model procedures and presented as least squares means obtained using SAS (version 9.4, SAS Institute Inc., Cary, NC) to perform multiple comparisons. The expression of proteins of interest in Western blot analyses was normalized based on the expression of total protein or $\alpha$-tubulin. All tests of significance were performed using the appropriate error terms according to the expectation of the mean squares for error. The Student's $t$ tests were used for comparisons of 2 sample means. All statistical analyses were evaluated as a 2 -sided $P$ value of 0.05 .

\section{RESULTS}

\section{Stimulatory Effect of CCL2 on Proliferation of MAC-T Cells}

To investigate dose-dependent effects of CCL2 $(0,1$, $5,10,25,50,100$, and $150 \mathrm{ng} / \mathrm{mL})$ on proliferation of MAC-T cells, cell proliferation assays were performed. Treatment of CCL2 increased proliferation of MAC-T cells by $121.8(P<0.05), 132.6(P<0.01), 145.7(P$ $<0.01)$, 146.5 $(P<0.05)$, and $120.1 \%(P<0.001)$ compared with $0 \mathrm{ng} / \mathrm{mL}$ at $10,25,50,100$, and $150 \mathrm{ng} /$

Table 2. Primer sets used in semiquantitative real-time PCR

\begin{tabular}{llll}
\hline Gene symbol & GenBank accession no. & Sense primer $\left(5^{\prime} \rightarrow 3^{\prime}\right)$ & Antisense primer $\left(5^{\prime} \rightarrow 3^{\prime}\right)$ \\
\hline$C C R 2$ & NM_001194959 & CATTCAGGTTATGCCTGTGC & TTGTTTGCAGAGGTGTTTGG \\
CCL2 & NM_174006 & CCACGCTGAAACTTGAATCC & TGTGGAGTGAGTGCTCAAGG \\
GAPDH & NM_001127891 & CACAGTCAAGGCAGAGAACG & CATAAGTCCCTCCACGATGC \\
\hline
\end{tabular}




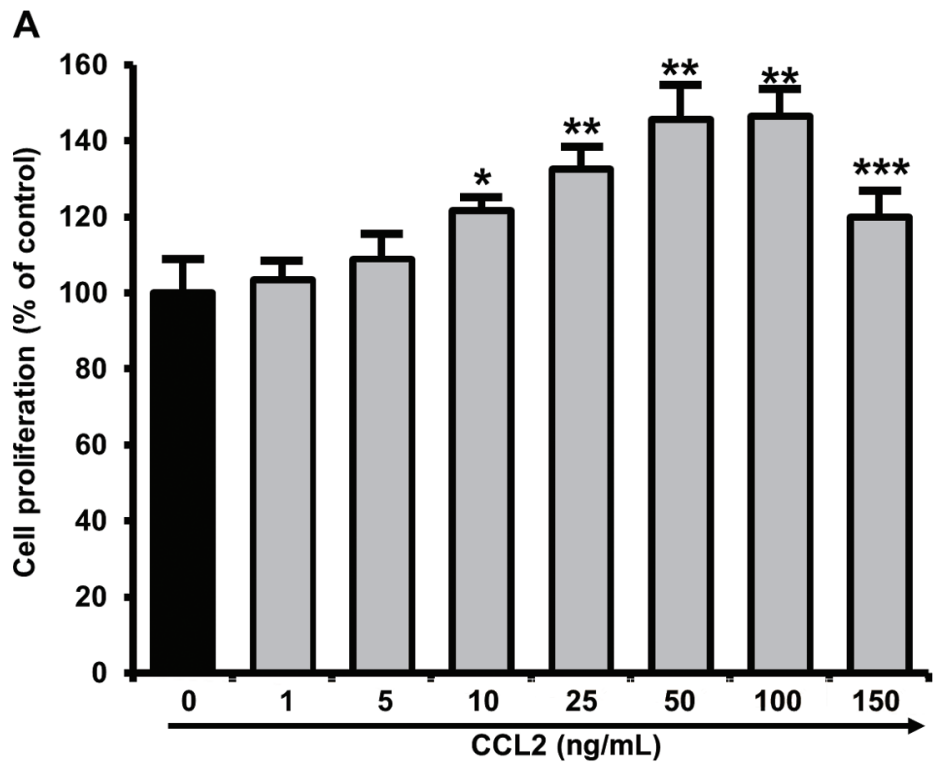

B
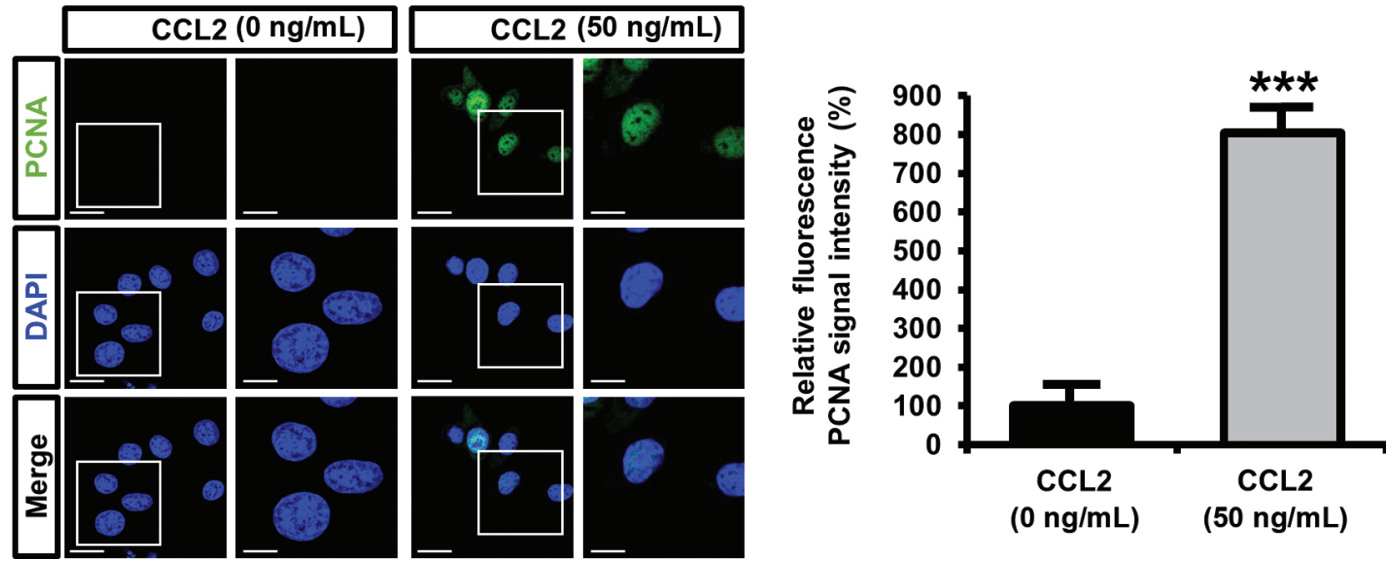

Figure 1. C-C motif chemokine ligand 2 (CCL2) stimulates proliferation of MAC-T cells. (A) Proliferation of MAC-T cells in response to CCL2 $(0,1,5,10,25,50,100$, and $150 \mathrm{ng} / \mathrm{mL})$ was analyzed using a 5-bromo-2'-deoxyuridine (BrdU) cell proliferation assay. Data are presented as percentages relative to nontreated MAC-T cells (100\%). (B) Immunoreactive proliferating cell nuclear antigen (PCNA) was detected in CCL2-treated and nontreated MAC-T cells using immunofluorescence confocal microscopy. Cell nuclei were counterstained with 4',6-diamidino2-phenylindole (DAPI). Scale bar represents $40 \mu \mathrm{m}$ (the first and third vertical panels) and $20 \mu \mathrm{m}$ (the second and fourth vertical panels). The fluorescence intensity was detected using Metamorph software (Molecular Devices, Sunnyvale, CA) and the graph indicates the intensity of PCNA green in CCL2-treated cells as compared with nontreated MAC-T cells. Error bars represent the SEM. The asterisks indicate significant effects of treatment $\left({ }^{* * *} P<0.001,{ }^{* *} P<0.01\right.$, and $\left.{ }^{*} P<0.05\right)$. Color version available online.

$\mathrm{ml}$, respectively (Figure 1A). Based on the results of this experiment, concentrations of CCL2 up to $50 \mathrm{ng} /$ $\mathrm{mL}$ were used in subsequent assays for cell proliferation. We also verified that the expression of PCNA, a DNA clamp protein essential for cell proliferation, was regulated by CCL2 in MAC-T cells. The PCNA was most abundant in MAC-T cells treated with $50 \mathrm{ng} / \mathrm{mL}$ of CCL2 and increased $804.6 \%(P<0.001)$ in cells also stained with DAPI to detect nuclei (Figure 1B). These results indicate that CCL2 stimulates proliferation of bovine mammary epithelial cells.

\section{CCL2 Regulates Stage of Cell Cycle in Bovine Mammary Epithelial Cells}

We analyzed the effect of CCL2 $(0,5,10,25$, and 50 $\mathrm{ng} / \mathrm{mL}$ ) on the cell cycle of MAC-T cells by measuring changes in the amount of DNA following staining for propidium iodide. The percentage of cells in the $\mathrm{G}_{2} / \mathrm{M}$ phase increased dose-dependently in response to CCL2 (Figure $2 \mathrm{~A}$ ). In response to $25 \mathrm{ng} / \mathrm{mL}$ of CCL2, the ratio of $\mathrm{G}_{2} / \mathrm{M}$ phase cells increased from $3.90 \%$ at $0 \mathrm{ng} /$ $\mathrm{mL}$ to $5.78 \%(P<0.05)$, and increased to $7.10 \%(P<$ 
$0.01)$ at $50 \mathrm{ng} / \mathrm{mL}$ of CCL2. Flow cytometric analyses confirmed a significant increase in abundances of cyclin D1 by CCL2 $(50 \mathrm{ng} / \mathrm{mL})$ treatment, as cyclin D1 regulates cell cycle progression (Figure $2 \mathrm{~B}$ ). The expression of cyclin D1 in nuclei of MAC-T cells was increased $590.1 \%$ in response to CCL2 $(P<0.001)$. These results indicated that CCL2 induced cell cycle progression of bovine mammary epithelial cells.

A

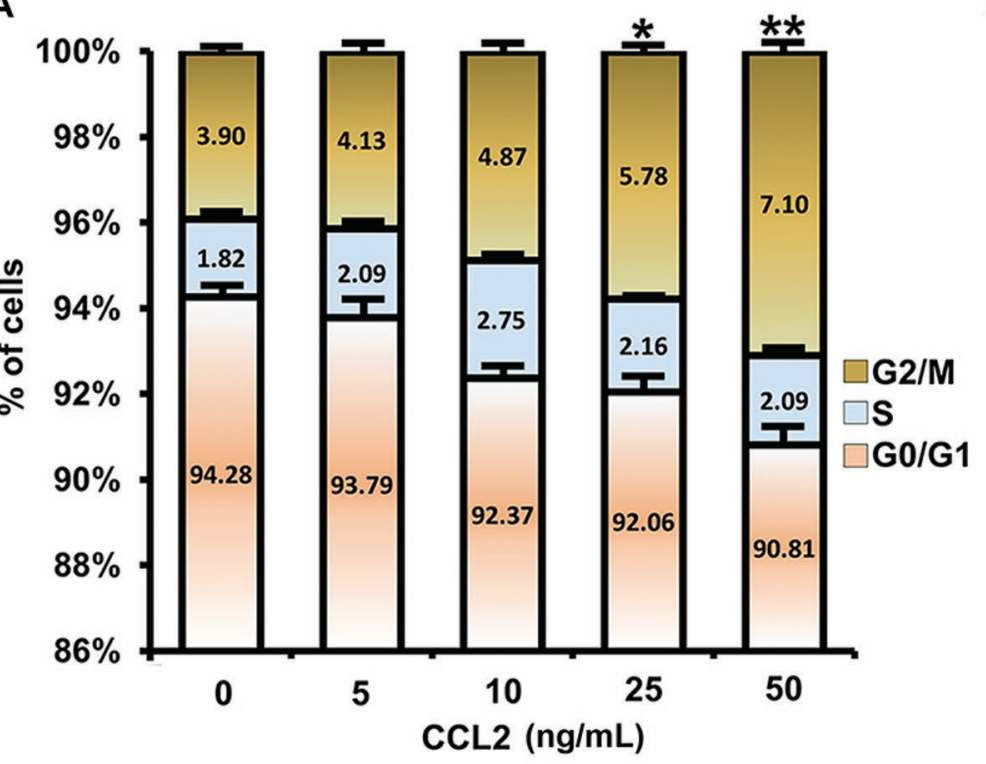

B
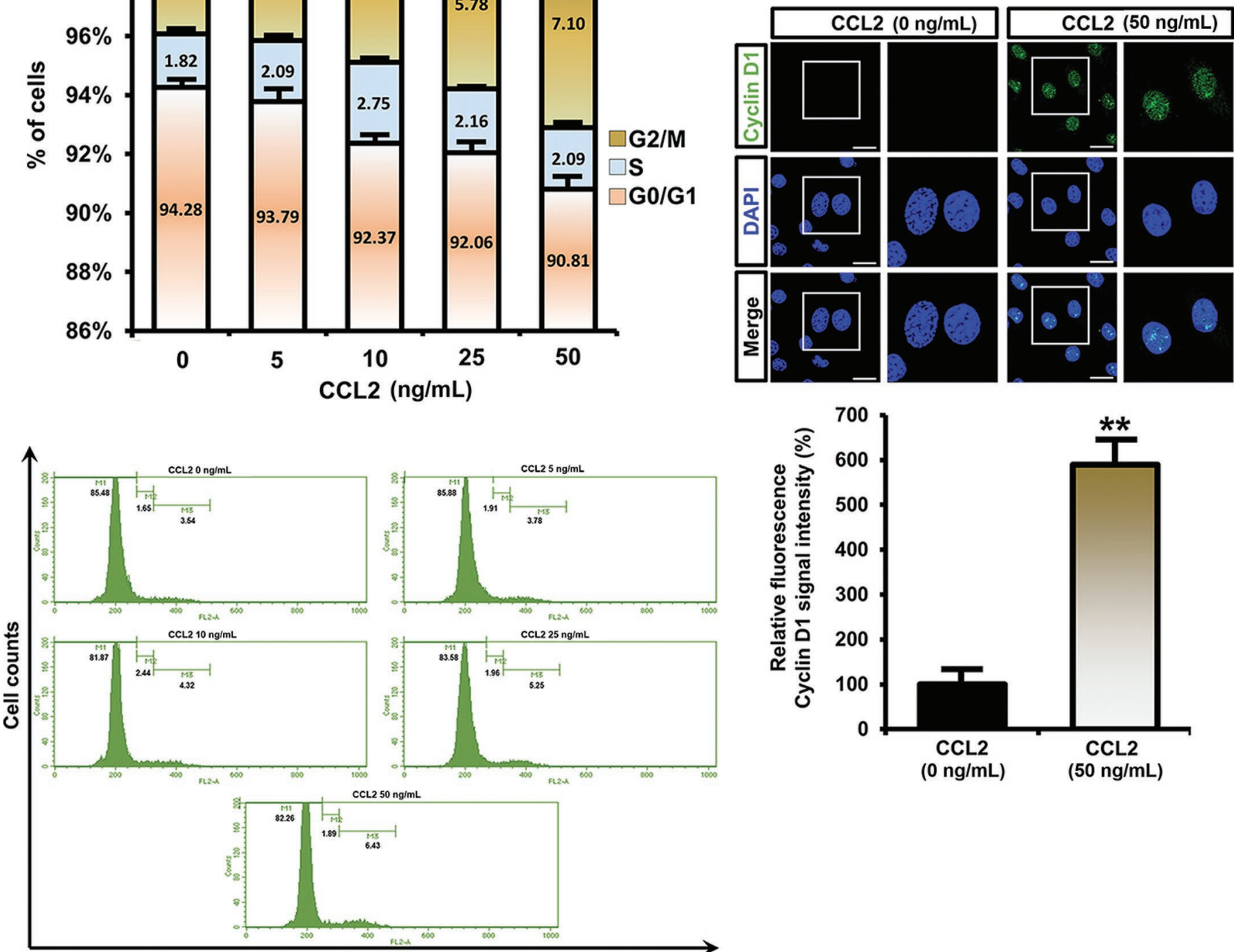

Fluorescence intensity (FL2-A)

Figure 2. Regulatory effects of C-C motif chemokine ligand 2 (CCL2) on the cell cycle of MAC-T cells. (A) Cell cycle analysis of MAC-T cells in response to CCL2 $(0,5,10,25$, and $50 \mathrm{ng} / \mathrm{mL})$. The flow cytometric data were obtained using propidium iodide (PI)-stained MAC-T cells and the results are shown as the percentage of cells in each phase of the cell cycle. (B) Abundances and localization of cyclin D1 proteins in CCL2-treated $(50 \mathrm{ng} / \mathrm{mL})$ or nontreated MAC-T cells were analyzed using immunofluorescence analyses. Cell nuclei were counterstained with 4',6-diamidino-2-phenylindole (DAPI; the second horizontal panels). Scale bar represents $40 \mu \mathrm{m}$ (the first and third vertical panels) and $20 \mu \mathrm{m}$ (the second and fourth vertical panels). The fluorescence intensity was detected using Metamorph software (Molecular Devices, Sunnyvale, CA) and the graph indicates the intensity of cyclin D1 green in CCL2-treated cells as compared with nontreated MAC-T cells. Error bars represent the SEM. The asterisks indicate significant differences compared with nontreated MAC-T cells $(* * P<0.01$ and $* P<0.05)$. Color version available online. 


\section{CCL2 Activates PI3K/AKT and MAPK Signaling Pathways in Bovine Mammary Epithelial Cells}

To investigate the activity of CCL2-regulated signal transduction kinases, we examined the phosphorylation of proteins involved in the PI3K/AKT and MAPK pathways. Phosphorylation (p) of AKT, P70S6K, and S6 increased in response to CCL2 in a dose-dependent manner $(0,5,10,25$, and $50 \mathrm{ng} / \mathrm{mL}$; Figure 3A-3C). In the case of p-AKT, CCL2 at 10, 25, and $50 \mathrm{ng} /$ $\mathrm{mL}$ increased abundances by $3.27(P<0.01), 13.12$ $(P<0.001)$, and 29.39 fold $(P<0.001)$, respectively, compared with control cells in the absence of CCL2. The abundances of p-P70S6K in MAC-T cells treated with 25 and $50 \mathrm{ng} / \mathrm{mL}$ of CCL2 were $4.18(P<0.01)$ and 4.40 fold $(P<0.001)$ greater, respectively, than for control MAC-T cells. When MAC-T cells were treated with 10,25 , and $50 \mathrm{ng} / \mathrm{mL}$ of CCL2, the abundances of p-S6 increased $5.56(P<0.001), 8.97(P<0.001)$, and 14.00 times $(P<0.001)$, respectively, compared with the control MAC-T cells. In addition, $50 \mathrm{ng} / \mathrm{mL}$ of CCL2 increased expression of p-ERK1/2 by 12.59 fold $(P<0.001)$, whereas 10 and $25 \mathrm{ng} / \mathrm{mL}$ of CCL2 induced increases of $8.40(P<0.001)$ and 12.15 fold $(P$ $<0.001$ ), respectively, compared with control MAC-T cells (Figure 3D). The expression of p-JNK was 1.94 $(P<0.01), 2.50(P<0.001)$, and 2.53 fold $(P<0.01)$ greater in MAC-T cells treated with 10, 25, and 50 $\mathrm{ng} / \mathrm{mL}$ of CCL2, respectively, compared with control MAC-T cells (Figure 3E). The expression of p-P38 in MAC-T cells increased in response to 25 (3.98 fold, $P$ $<0.01)$ and $50 \mathrm{ng} / \mathrm{mL}(4.41$ fold, $P<0.01)$ of CCL2 compared with that for MAC-T cells not treated with CCL2 (Figure 3F). In addition, phosphorylation of cyclin D1 increased in response to CCL2 (Figure 3G). The expression of p-cyclin D1) increased $2.81(P<$ $0.01), 2.75(P<0.05), 12.40(P<0.001)$, and 18.29 $(P<0.001)$ times in MAC-T cells in response to 5 , 10,25 , and $50 \mathrm{ng} / \mathrm{mL}$ of CCL2, respectively, compared with control MAC-T cells. Wortmannin (PI3K/AKT inhibitor, $1 \mu M$ ), U0126 (ERK1/2 inhibitor, $20 \mu M$ ), and SP600125 (JNK inhibitor, $20 \mu M$ ) were used to identify signal transduction proteins activated by CCL2 to increase proliferation of MAC-T cells. Inhibition of PI3K/AKT $(29.7 \%, P<0.01)$, ERK1 $/ 2(38.7 \%, P<$ $0.01)$, and JNK $(29.9 \%, P<0.05)$ prevented CCL2 from increasing proliferation of MAC-T cells (Figure 4A). Also, the activities of the signal transduction proteins regulated by CCL2 were analyzed after pretreatment with inhibitors. The abundances of AKT, P70S6K, and S6, which belong to the PI3K/AKT signaling pathway, were reduced when MAC-T cells were treated with both Wortmannin and CCL2 (Figure 4B-4D). In ad- dition, pretreatment of MAC-T cells with U0126 and SP600125 increased the expression of p-AKT compared with effects of CCL2 alone. However, the phosphorylation of P70S6K did not change in response to pretreatment of inhibitors other than Wortmannin. The U0126 significantly reduced CCL2-induced expression of p-S6, but pretreatment with SP600125 did not significantly reduce CCL2 induction of S6 in MAC-T cells. Expression of p-ERK1/2 increased in response to CCL2, and this effect was increased further in MAC-T cells by Wortmannin or SP600125 pretreatment (Figure 4E). On the other hand, the expression of p-JNK was significantly increased by CCL2 and further increased by pretreatment of MAC-T cells with Wortmannin or U0126 (Figure 4F). Phosphorylation of P38 was increased by CCL2 alone, as well as by pretreatment of MAC-T cells with Wortmannin (Figure 4G). Phosphorylation of cyclin D1 in response to CCL2 was significantly decreased when MAC-T cells were pretreated with either U0126 or SP600125 (Figure 4H). Based on those results, CCL2activated PI3K/AKT and MAPK signaling pathways play an important role in the regulation of proliferation and cell cycle by CCL2 in bovine mammary epithelial cells. Also, cross-talk exists among those signaling pathways for regulation of effects of CCL2 to induce proliferation of bovine mammary epithelial cells.

\section{CCL2 Alleviates ER Stress in Bovine Mammary Epithelial Cells}

The effect of treating MAC-T cells with CCL2 (50 $\mathrm{ng} / \mathrm{mL}$ ) was to alleviate ER stress otherwise induced by treatment of the cells with tunicamycin $(0.25 \mu \mathrm{g} /$ $\mathrm{mL}$ ). Tunicamycin decreased cell proliferation by $30.2 \%$ $(P<0.01)$, whereas co-treatment of cells with both tunicamycin and CCL2 decreased cell proliferation by only $16.9 \%(P<0.05)$ compared with nontreated control cells (Figure 5A). In addition, CCL2 reduced the expression of ER stress sensor proteins increased by tunicamycin. Three major proteins in induction of ER stress were inositol-requiring protein $1 \alpha($ IRE1 $\alpha)$, activating transcription factor $6 \alpha$ (ATF6 $\alpha$ ), and protein kinase RNA-like ER kinase (PERK), all of which were regulated by CCL2 in MAC-T cells (Figure 5B5D). The expression of IRE1 $\alpha$, ATF6 $\alpha$, and p-PERK decreased $82.5(P<0.01), 45.9(P<0.05)$, and $93.0 \%$ $(P<0.001)$, respectively, when treated with CCL2 and tunicamycin as compared with treatment of MAC-T cells with tunicamycin alone. In particular, phosphorylation of eukaryotic translation initiator factor $2 \alpha$ $(\mathbf{e I F} \mathbf{\alpha})$, which is directly regulated by the activation of PERK, was significantly reduced by $96.7 \%(P<$ 0.001) in MAC-T cells treated with both tunicamycin 


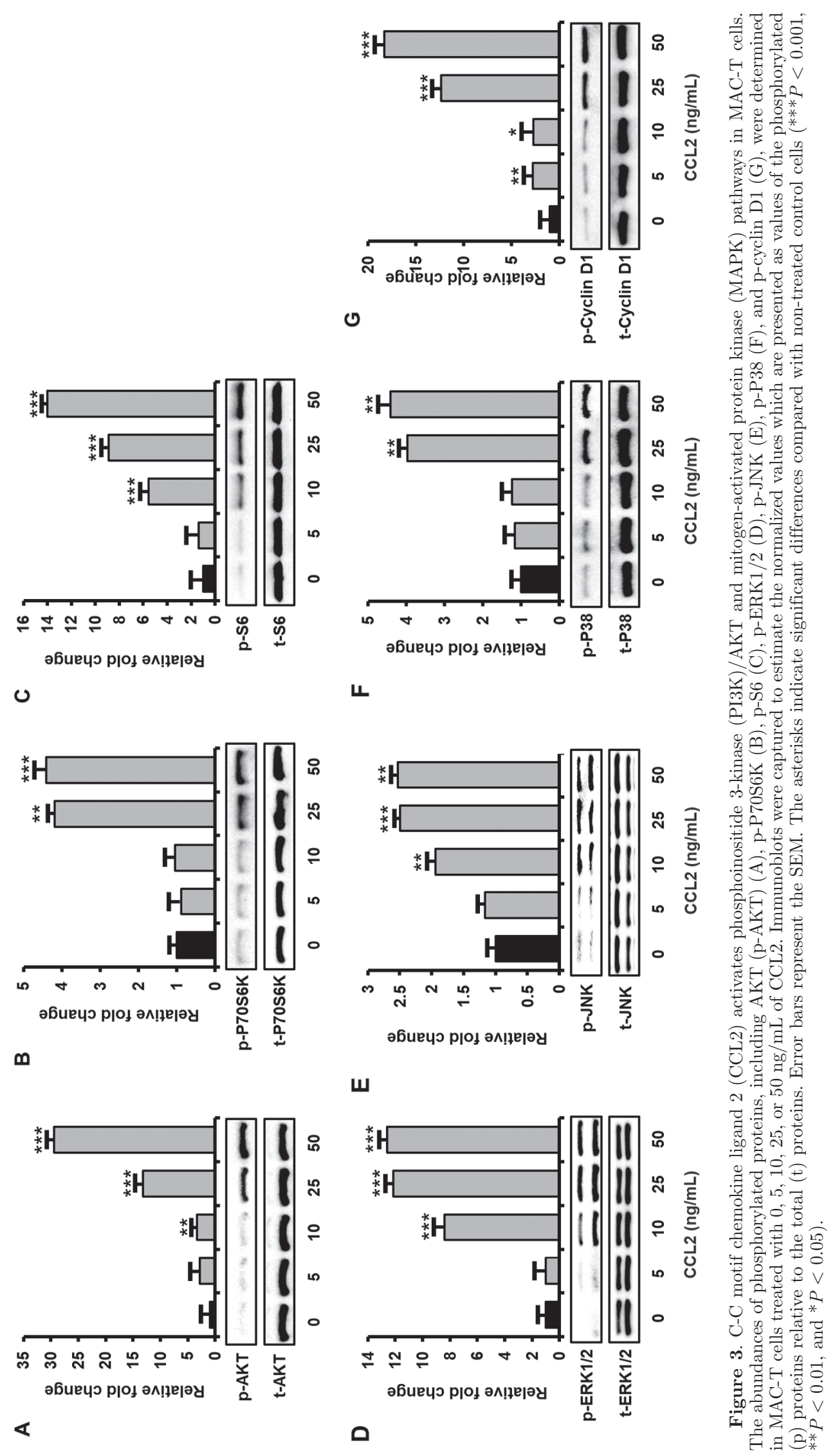



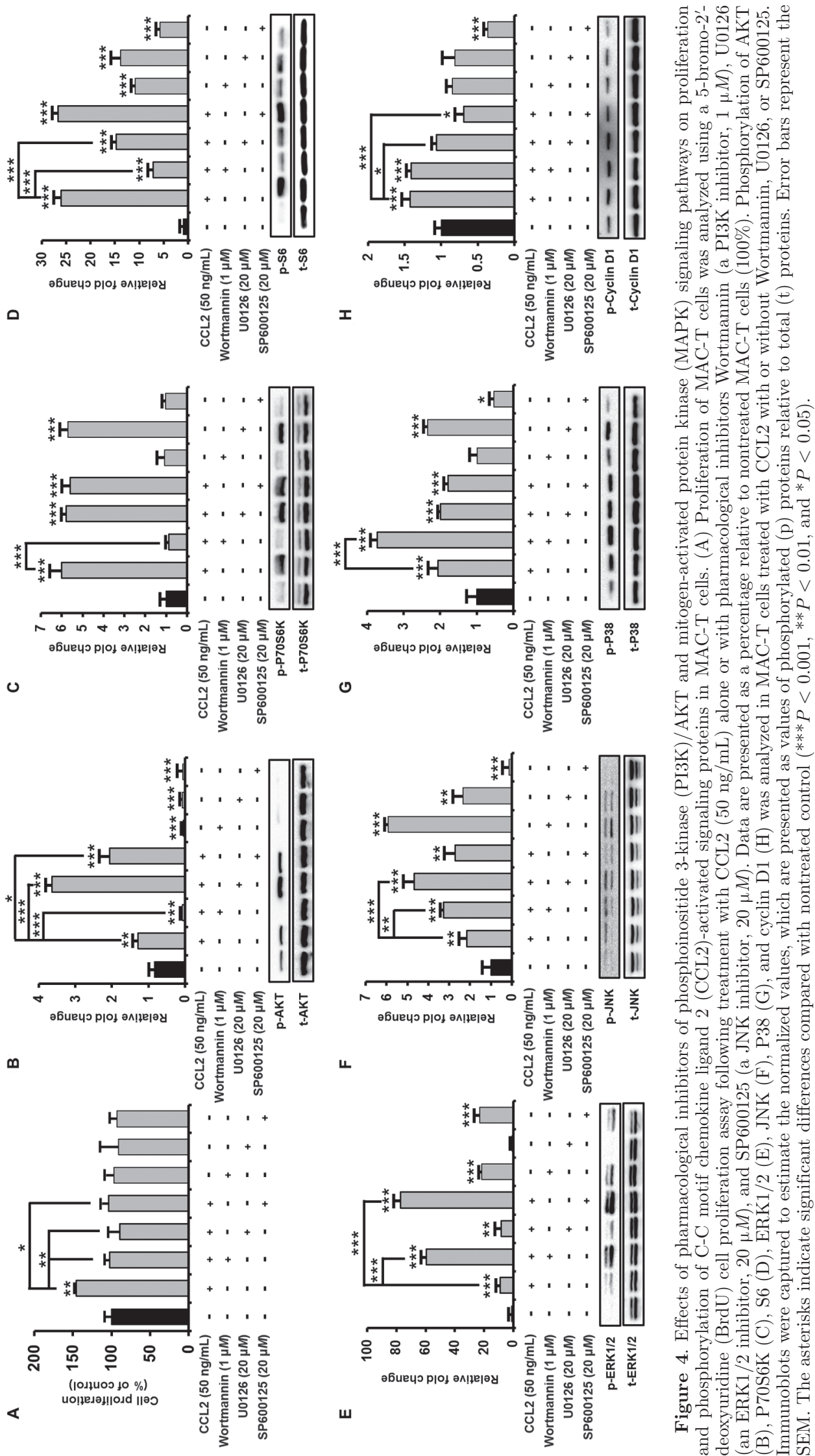


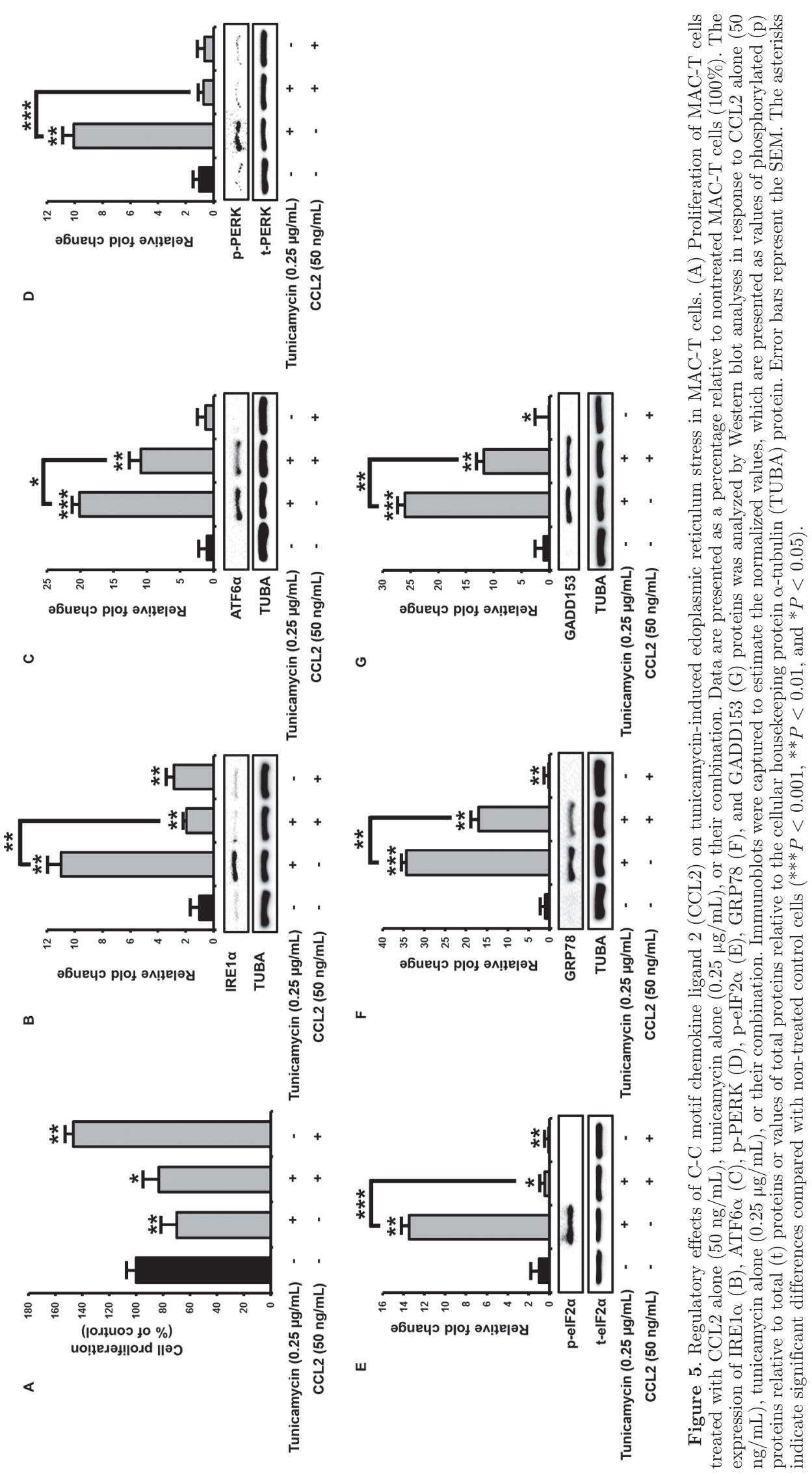


and CCL2 compared with treatment of the cells with tunicamycin alone (Figure 5E). Also, the expression of glucose-regulated protein 78 (GRP78), an ER chaperone protein essential for ER stress responses, was reduced CCL2 in cells also treated with tunicamycin $(50.3 \%, P<0.01$; Figure 5F). Growth arrest and DNA damage 153 (GADD153), also known as C/EBP homologous protein $(\mathrm{CHOP})$, is a transcription factor that responds to cellular stress and leads to apoptosis. The CCL2 reduced the expression of GADD153, which was increased by tunicamycin in MAC-T cells $(54.6 \%$, $P<0.01 ;$ Figure 5G). These results indicate that CCL2 alleviates ER stress in bovine mammary epithelial cells.

\section{CCL2 Reduced Inflammatory Response Induced by LPS in Bovine Mammary Epithelial Cells}

To investigate whether CCL2 has an anti-inflammatory effect in bovine mammary epithelial cells, MAC-T cells were treated with LPS $(0,0.5,1$, and $5 \mu \mathrm{g} / \mathrm{mL})$ in a dose-dependent manner. Lipopolysaccharide increased the expression of $I L 8$ and IL $6 \mathrm{mRNA}$ in a dosedependent manner (Figure 6A and 6B). Expression of
IL 8 and IL 6 mRNA increased by $7.03(P<0.001)$ and $3.27(P<0.001)$ times in response to $5 \mu \mathrm{g} / \mathrm{mL}$ of LPS, respectively, compared with the control group. Interestingly, CCL2 significantly decreased the expression of IL-8 and IL6, which was otherwise increased by $5 \mu \mathrm{g} /$ $\mathrm{mL}$ of LPS. Moreover, the expression of NFKB1 mRNA was also reduced when MAC-T cells were treated with CCL2 compared with treatment with only LPS (Figure $6 \mathrm{C}$ ). Lipopolysaccharide inhibited proliferation of MAC-T cells in a dose-dependent manner, which was restored when the cells were treated with CCL2 (Figure $6 \mathrm{D})$. The proliferation of MAC-T cells was decreased by $15.7(P<0.01), 22.9(P<0.05)$, and $31.1 \%(P<$ 0.01 ) in response to $0.5,1$, and $5 \mu \mathrm{g} / \mathrm{mL}$ of LPS, respectively. Addition of $25 \mathrm{ng} / \mathrm{mL}$ of CCL2 increased cell proliferation $137.5 \%(P<0.05)$ compared with effects of $5 \mu \mathrm{g} / \mathrm{mL}$ of LPS alone, and proliferation of MAC-T cells increased $150.8 \%(P<0.01)$ in response to $50 \mathrm{ng} /$ $\mathrm{mL}$ of CCL2. However, inhibition of signal transduction proteins by Wortmannin, U0126, and SP600125 inhibited the ability of CCL2 to stimulate proliferation of MAC-T cells. Compared with MAC-T cells treated with LPS $(5 \mu \mathrm{g} / \mathrm{mL})$ and CCL2 $(50 \mathrm{ng} / \mathrm{mL})$, proliferation of
A

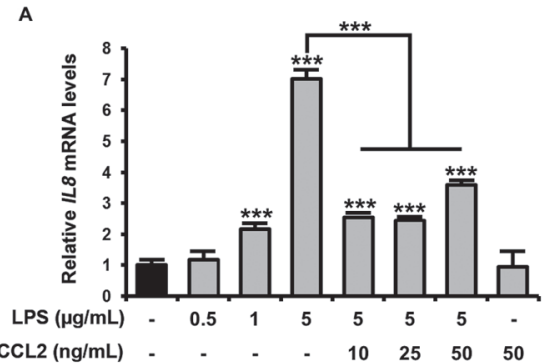

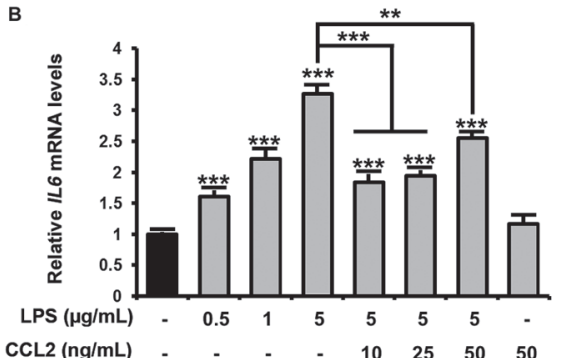

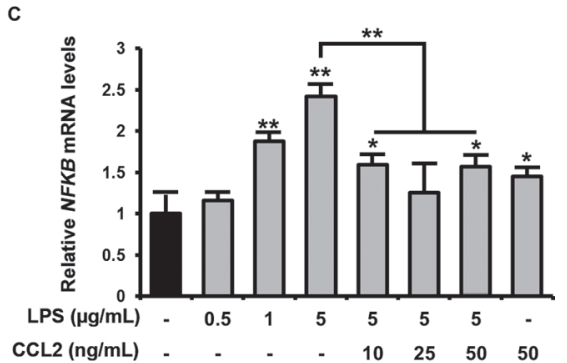

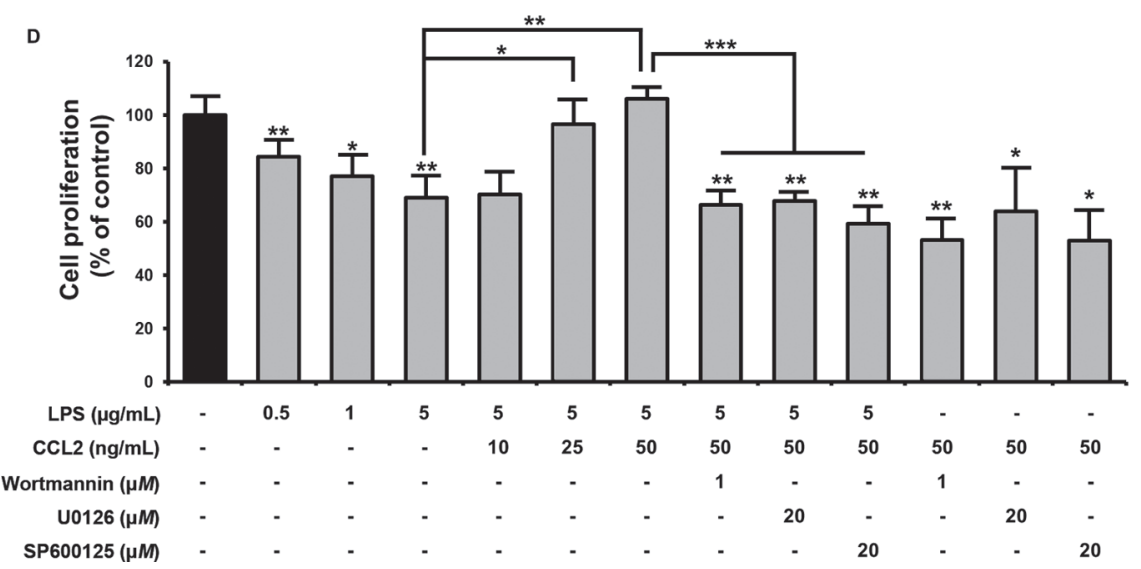

Figure 6. C-C motif chemokine ligand 2 (CCL2) alleviates LPS-induced inflammatory responses in MAC-T cells. Expression of IL8 (A), IL6 (B), and NFKB1 (C) mRNA in response to LPS $(0.5,1$, and $5 \mu \mathrm{g} / \mathrm{mL})$ with or without CCL2 (10, 25, and $50 \mathrm{ng} / \mathrm{mL})$. Data are presented as a fold-change relative to nontreated MAC-T cells. (D) Proliferation of MAC-T cells in response to LPS $(0.5,1$, and $5 \mu \mathrm{g} / \mathrm{mL})$ with or without CCL2 $(10,25$, and $50 \mathrm{ng} / \mathrm{mL})$, Wortmannin $(1 \mu M)$, U0126 $(20 \mu M)$, or SP600125 $(20 \mu M)$. Data are presented as a percentage relative to nontreated MAC-T cells $(100 \%)$. Error bars represent the SEM. The asterisks indicate significant differences compared with nontreated control cells $\left(* * * P<0.001,{ }^{* *} P<0.01\right.$, and $\left.{ }^{*} P<0.05\right)$. 
cells treated with Wortmannin $(1 \mu M)$, U0126 $(20 \mu M)$, and SP600125 $(20 \mu M)$ was decreased $37.4(P<0.001)$, $35.9(P<0.001)$, and $44.2 \%(P<0.001)$, respectively. These results suggest that the anti-inflammatory effect of CCL2 prevents LPS-induced antiproliferative effects and mediates the induction of PI3K/AKT and MAPK signaling pathways in bovine mammary epithelial cells.

\section{DISCUSSION}

The number of mammary epithelial cells peaks during early lactation and then declines gradually, with apoptosis predominating over cell proliferation (Capuco et al., 2001). This trend is consistent with milk production, which decreases about $23 \%$ between d 90 and 240 of lactation in cows; thus, maintaining high levels of cell proliferation is important for milk yields. Results of many experiments using human and bovine mammary gland cells have shown that hormones such as epidermal growth factor and prolactin activate various signaling pathways to increase milk yields (Das and Vonderhaar, 1996; Pauloin and Chanat, 2012). Among them, activation of the PI3K/AKT and MAPK signaling pathways is closely correlated with proliferation of mammary epithelial cells (Leibowitz and Cohick, 2009). We used in vitro cultured MAC- $\mathrm{T}$ cells, a mammary epithelial cell line, to identify factors the increase proliferation of MAC-T cells by activating 2 signal transduction pathways. The MAC-T cells are useful in vitro models because they increase proliferation in response to a variety of growth factors known to promote mammary gland growth and development, including epidermal growth factor and insulin growth factors (Fleming et al., 2006).

Many chemokines found in mammary glands are also known to regulate the differentiation of mammary epithelial cells directly or indirectly, such as growth hormone, which exhibits chemotactic activity in mammary tissue. For instance, macrophage colony-stimulating factor 1 is necessary for macrophage infiltration into the mammary gland, where it regulates the invasion of mammary epithelial cells and induces signal transduction pathways associated with angiogenesis (GouonEvans et al., 2002). Chemerin, which promotes migration of macrophages to inflammatory response sites, regulates the expression of genes related to lactogenesis in MAC-T cells (Suzuki et al., 2015). However, a lack of research exists as to whether chemokines are involved in the proliferation of mammary epithelial cells. We confirmed that CCL2 dose-dependently increased the proliferation of MAC-T cells; CCL2 activates PI3K/ AKT and MAPK signaling pathways and promotes cell survival in breast and prostate cancers when it binds to its receptor C-C chemokine receptor 2 (CCR2; Fang et al., 2012, Qian et al., 2010). We confirmed expression of CCR2 mRNA, as well as CCL2 in MAC-T cells (Supplemental Figure S1; https://doi.org/10.3168/ jds.2017-13996); CCR2, a superfamily of G proteincoupled receptor, is overexpressed in breast cancer cells compared with normal breast epithelial cells in mice, and is also a target protein for breast cancer therapy (Chen et al., 2016). Treatment with CCL2 of MAC-T cells activated PI3K/AKT (AKT, P70S6K, and S6) and MAPK (ERK1/2, JNK and P38) proteins, whereas inhibition of AKT, ERK1/2, and JNK inhibited the increase in proliferation of MAC-T cells in response to CCL2. Those results indicated that CCL2 stimulation of proliferation of MAC-T cells is mainly mediated by 2 signaling pathways, and that the increase in cell proliferation is coordinated with increases in the expression of PCNA and cyclin D1. Cyclin D1 increases during the G2 phase of the cell cycle and plays a key role in the on-going progression of the cell cycle (Stacey, 2003). In general, PI3K/AKT and MAPK signaling pathways have a crosstalk effect and regulate cell survival and proliferation, which is also true in breast epithelial cells (Misra et al., 2006; Rauch et al., 2012; Niba et al., 2013). The signal transduction pathways activated by CCL2 are presumed to have a regulatory effect on each other in MAC-T cells, as shown in Figure 7. In addition, inhibition of the MAPK signaling proteins (ERK1/2 and JNK) seem to inhibit the activity of cyclin D1, which is increased by CCL2 in MAC-T cells.

The GRP78, an ER chaperone protein that plays an essential role in UPR, is deeply involved in cell signaling pathways involving PI3K/AKT and MAPK (Misra et al., 2006). Expression of IRE1 $\alpha$, ATF6 $\alpha$, and p-PERK, which function as ER stress sensors as well as major UPR transducers regulated by GRP78, were reduced by CCL2 when MAC-T cells were co-treated with tunicamycin. This alteration in expression leads to changes in the expression of GADD153, which is a link between apoptosis and severe ER stress. Previous studies conjectured that regulating ER stress may be important for development of the bovine mammary gland, as the expression of the ER stress component genes changes dynamically in bovine mammary tissue during lactation (Invernizzi et al., 2012). To the best of our best knowledge, along with our previous study, this is the first report of a ligand, CCL2, that attenuates ER stress in bovine mammary epithelial cells (Kang et al., 2017).

Many gram-negative bacteria in the bovine rumen may produce LPS (Khafipour et al., 2009); LPSinduced systemic inflammation in a low-pH intestinal environment has a significant effect on the quality and 
quantity of milk (Esposito et al., 2014). Therefore, inhibition of production of proinflammatory cytokines, including IL-8, IL-6, and tumor necrosis factor $\alpha$ by endogenous LPS, is necessary to prevent chronic mastitis and maintain a normal lactation (Fan et al., 2016). In addition, LPS inhibits the PI3K/AKT signaling transduction pathway including AKT, mammalian target of rapamycin, and P70 ribosomal protein S6 kinase (P70S6K), and reduces the viability and proliferation of bovine mammary epithelial cells (Liu et al., 2015). For these reasons, bovine mastitis is an important is- sue in the dairy industry because it causes economic losses by reducing the quantity and quality of milk (Zhao and Lacasse, 2008). To overcome this problem, antibiotics have been used for a long time, which is now of concern to consumers. In response to concerns of society, researchers are interested in factors that have anti-inflammatory effects in bovine mammary epithelial cells (Jeong et al., 2017; Yu et al., 2017). In MAC-T

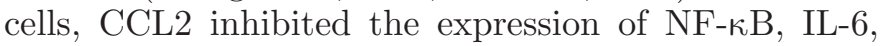
and IL-8, which were increased by LPS, and restored proliferation of MAC-T cells. However, the proliferative

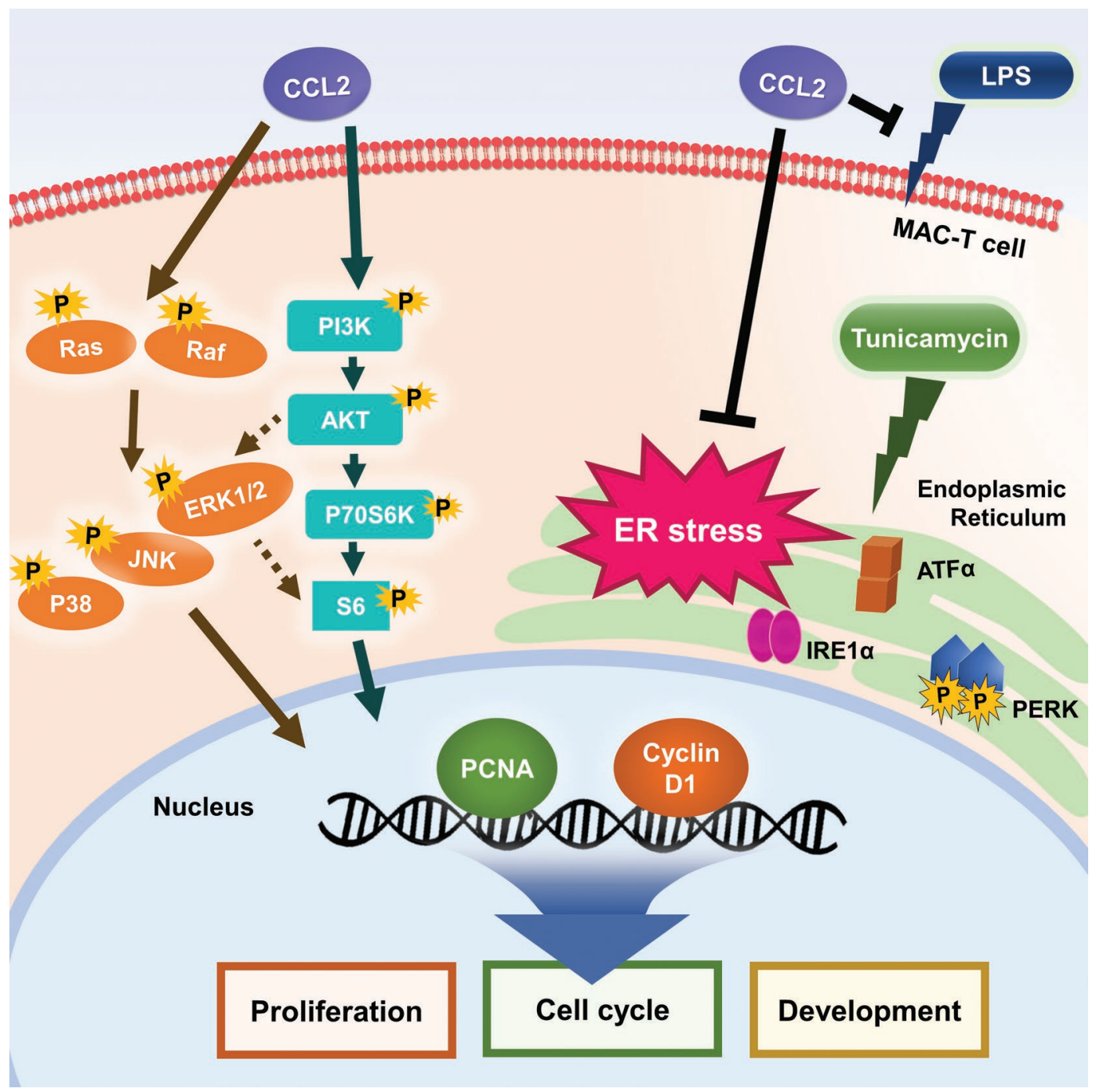

Figure 7. The schematic diagram shows the current working hypothesis of C-C motif chemokine ligand 2 (CCL2)-induced signal transduction pathways for regulation of endoplasmic reticulum (ER) stress and LPS-induced inflammatory responses in bovine mammary epithelial cells. CCL2 binds to C-C chemokine receptor 2 (CCR2) and activates phosphorylation (P) of proteins within phosphoinositide 3-kinase (PI3K)/AKT (AKT, P70S6K, and S6) and mitogen-activated protein kinase (MAPK) (ERK1/2, JNK, and P38) signaling pathways in MAC-T cells. Also, CCL2 alleviates tunicamycin-induced ER stress in MAC-T cells, as evidenced by expression of IRE1 $\alpha$, ATF6 $\alpha$, and p-PERK. CCL2 increases the expression of proliferating cell nuclear antigen (PCNA) and cyclin D1 in nuclei of MAC-T cells, exerts regulatory effects on proliferation and cell cycle progression protein cyclin D1, and attenuates LPS-induced inflammation in MAC-T cells. Color version available online. 
effects of CCL2 are presumed to be regulated by PI3K/ AKT and MAPK signaling pathways in cells treated with LPS.

\section{CONCLUSIONS}

In conclusion, CCL2 stimulates cell cycle progression and proliferation of bovine mammary epithelial cells. It also stimulates phosphorylation of PI3K/AKT and MAPK, proteins involved in the proliferation of bovine mammary epithelial cells; likewise, CCL2 attenuates ER stress and inflammatory responses in bovine mammary epithelial cells.

\section{ACKNOWLEDGMENTS}

This research was supported by a Korea University Grant and we also appreciate School of Life Sciences and Biotechnology for BK21 PLUS, Korea University for supporting the publication fee.

\section{REFERENCES}

Bauman, D. E., K. J. Harvatine, and A. L. Lock. 2011. Nutrigenomics, rumen-derived bioactive fatty acids, and the regulation of milk fat synthesis. Annu. Rev. Nutr. 31:299-319.

Bobrovnikova-Marjon, E., G. Hatzivassiliou, C. Grigoriadou, M Romero, D. R. Cavener, C. B. Thompson, and J. A. Diehl. 2008. PERK-dependent regulation of lipogenesis during mouse mammary gland development and adipocyte differentiation. Proc. Natl. Acad. Sci. USA 105:16314-16319.

Bulgari, O., X. Dong, A. L. Roca, A. M. Caroli, and J. J. Loor. 2017. Innate immune responses induced by lipopolysaccharide and lipoteichoic acid in primary goat mammary epithelial cells. J. Anim. Sci. Biotechnol. 8:29.

Capuco, A. V., D. L. Wood, R. Baldwin, K. McLeod, and M. J. Paape. 2001. Mammary cell number, proliferation, and apoptosis during a bovine lactation: Relation to milk production and effect of bST. J. Dairy Sci. 84:2177-2187.

Chen, X., Y. Wang, D. Nelson, S. Tian, E. Mulvey, B. Patel, I. Conti, J. Jaen, and B. J. Rollins. 2016. CCL2/CCR2 regulates the tumor microenvironment in HER-2/neu-driven mammary carcinomas in mice. PLoS One 11:e0165595.

Das, R., and B. K. Vonderhaar. 1996. Activation of raf-1, MEK, and MAP kinase in prolactin responsive mammary cells. Breast Cancer Res. Treat. 40:141-149.

Dessauge, F., V. Lollivier, B. Ponchon, R. Bruckmaier, L. Finot, S. Wiart, E. Cutullic, C. Disenhaus, S. Barbey, and M. Boutinaud. 2011. Effects of nutrient restriction on mammary cell turnover and mammary gland remodeling in lactating dairy cows. J. Dairy Sci. 94:4623-4635.

Esposito, G., P. C. Irons, E. C. Webb, and A. Chapwanya. 2014. Interactions between negative energy balance, metabolic diseases, uterine health and immune response in transition dairy cows. Anim. Reprod. Sci. 144:60-71.

Fan, W. J., H. P. Li, H. S. Zhu, S. P. Sui, P. G. Chen, Y. Deng, T. M. Sui, and Y. Y. Wang. 2016. NF-kappaB is involved in the LPSmediated proliferation and apoptosis of MAC-T epithelial cells as part of the subacute ruminal acidosis response in cows. Biotechnol. Lett. 38:1839-1849.

Fang, W. B., I. Jokar, A. Zou, D. Lambert, P. Dendukuri, and N. Cheng. 2012. CCL2/CCR2 chemokine signaling coordinates survival and motility of breast cancer cells through Smad3 protein- and p42/44 mitogen-activated protein kinase (MAPK)-dependent mechanisms. J. Biol. Chem. 287:36593-36608.

Flaishon, L., G. Hart, E. Zelman, C. Moussion, V. Grabovsky, G. Lapidot Tal, S. Feigelson, R. Margalit, A. Harmelin, T. Avin-Wittenberg, D. Shoseyov, R. Alon, J. P. Girard, and I. Shachar. 2008. Anti-inflammatory effects of an inflammatory chemokine: CCL2 inhibits lymphocyte homing by modulation of CCL21-triggered integrin-mediated adhesions. Blood 112:5016-5025.

Fleming, J. M., G. Desury, T. A. Polanco, and W. S. Cohick. 2006. Insulin growth factor-I and epidermal growth factor receptors recruit distinct upstream signaling molecules to enhance AKT activation in mammary epithelial cells. Endocrinology 147:6027-6035.

Gouon-Evans, V., E. Y. Lin, and J. W. Pollard. 2002. Requirement of macrophages and eosinophils and their cytokines/chemokines for mammary gland development. Breast Cancer Res. 4:155-164.

Haug, A., A. T. Hostmark, and O. M. Harstad. 2007. Bovine milk in human nutrition-A review. Lipids Health Dis. 6:25.

Hou, X., L. Lin, W. Xing, Y. Yang, X. Duan, Q. Li, X. Gao, and Y. Lin. 2016. Spleen tyrosine kinase regulates mammary epithelial cell proliferation in mammary glands of dairy cows. J. Dairy Sci. 99:3858-3868.

Huynh, H. T., G. Robitaille, and J. D. Turner. 1991. Establishment of bovine mammary epithelial cells (MAC-T): An in vitro model for bovine lactation. Exp. Cell Res. 197:191-199.

Invernizzi, G., A. Naeem, and J. J. Loor. 2012. Short communication: Endoplasmic reticulum stress gene network expression in bovine mammary tissue during the lactation cycle. J. Dairy Sci. 95:2562-2566.

Jeong, C. H., W. N. Cheng, H. Bae, K. W. Lee, S. M. Han, M. C. Petriello, H. G. Lee, H. G. Seo, and S. G. Han. 2017. Bee venom decreases LPS-induced inflammatory responses in bovine mammary epithelial cells. J. Microbiol. Biotechnol. 27:1827-1836.

Jin, X., K. Wang, H. Liu, F. Hu, F. Zhao, and J. Liu. 2016. Protection of bovine mammary epithelial cells from hydrogen peroxideinduced oxidative cell damage by resveratrol. Oxid. Med. Cell. Longev. 2016:2572175.

Kang, M., W. Jeong, H. Bae, W. Lim, F. W. Bazer, and G. Song. 2017. Bifunctional role of ephrin A1-Eph system in stimulating cell proliferation and protecting cells from cell death through the attenuation of ER stress and inflammatory responses in bovine mammary epithelial cells. J. Cell. Physiol. 233:2560-2571.

Khafipour, E., D. O. Krause, and J. C. Plaizier. 2009. A grain-based subacute ruminal acidosis challenge causes translocation of lipopolysaccharide and triggers inflammation. J. Dairy Sci. 92:10601070 .

Kitamura, T., B. Z. Qian, D. Soong, L. Cassetta, R. Noy, G. Sugano, Y. Kato, J. Li, and J. W. Pollard. 2015. CCL2-induced chemokine cascade promotes breast cancer metastasis by enhancing retention of metastasis-associated macrophages. J. Exp. Med. 212:10431059

Leibowitz, B. J., and W. S. Cohick. 2009. Endogenous IGFBP-3 is required for both growth factor-stimulated cell proliferation and cytokine-induced apoptosis in mammary epithelial cells. J. Cell. Physiol. 220:182-188.

Liu, L., Y. Lin, L. Liu, Y. Bian, L. Zhang, X. Gao, and Q. Li. 2015. 14-3-3gamma regulates lipopolysaccharide-induced inflammatory responses and lactation in dairy cow mammary epithelial cells by inhibiting NF-kappaB and MAPKs and up-regulating mTOR signaling. Int. J. Mol. Sci. 16:16622-16641.

Misra, U. K., R. Deedwania, and S. V. Pizzo. 2006. Activation and cross-talk between Akt, NF-kappaB, and unfolded protein response signaling in 1-LN prostate cancer cells consequent to ligation of cell surface-associated GRP78. J. Biol. Chem. 281:13694-13707.

Niba, E. T., H. Nagaya, T. Kanno, A. Tsuchiya, A. Gotoh, C. Tabata, K. Kuribayashi, T. Nakano, and T. Nishizaki. 2013. Crosstalk between PI3 kinase/PDK1/Akt/Rac1 and Ras/Raf/MEK/ERK pathways downstream PDGF receptor. Cell. Physiol. Biochem. 31:905-913.

Nissen, A., E. Bendixen, K. L. Ingvartsen, and C. M. Rontved. 2013 Expanding the bovine milk proteome through extensive fractionation. J. Dairy Sci. 96:7854-7866. 
Pauloin, A., and E. Chanat. 2012. Prolactin and epidermal growth factor stimulate adipophilin synthesis in $\mathrm{HC} 11$ mouse mammary epithelial cells via the PI3-kinase/Akt/mTOR pathway. Biochim. Biophys. Acta 1823:987-996.

Qian, D. Z., B. L. Rademacher, J. Pittsenbarger, C. Y. Huang, A. Myrthue, C. S. Higano, M. Garzotto, P. S. Nelson, and T. M. Beer. 2010. CCL2 is induced by chemotherapy and protects prostate cancer cells from docetaxel-induced cytotoxicity. Prostate 70:433-442.

Rauch, J., W. Kolch, and M. Mahmoudi. 2012. Cell type-specific activation of AKT and ERK signaling pathways by small negativelycharged magnetic nanoparticles. Sci. Rep. 2:868.

Stacey, D. W. 2003. Cyclin D1 serves as a cell cycle regulatory switch in actively proliferating cells. Curr. Opin. Cell Biol. 15:158-163.

Sun, X., D. J. Glynn, L. J. Hodson, C. Huo, K. Britt, E. W. Thompson, L. Woolford, A. Evdokiou, J. W. Pollard, S. A. Robertson, and W. V. Ingman. 2017. CCL2-driven inflammation increases mammary gland stromal density and cancer susceptibility in a transgenic mouse model. Breast Cancer Res. 19:4.

Suzuki, Y., S. Haga, D. Katoh, K. H. So, K. C. Choi, U. S. Jung, H. G. Lee, K. Katoh, and S. G. Roh. 2015. Chemerin is a novel regulator of lactogenesis in bovine mammary epithelial cells. Biochem. Biophys. Res. Commun. 466:283-288.

Wang, M. Z., Y. Ji, C. Wang, L. M. Chen, H. R. Wang, and J. J. Loor. 2016. The preliminary study on the effects of growth hormone and insulin-like growth factor-I on kappa-casein synthesis in bovine mammary epithelial cells in vitro. J. Anim. Physiol. Anim. Nutr. (Berl.) 100:251-255.

Yu, G. M., H. Kubota, M. Okita, and T. Maeda. 2017. The antiinflammatory and antioxidant effects of melatonin on LPS-stimulated bovine mammary epithelial cells. PLoS One 12:e0178525.

Zhao, X., and P. Lacasse. 2008. Mammary tissue damage during bovine mastitis: Causes and control. J. Anim. Sci. 86(Suppl):57-65. 